\title{
High telomerase is a hallmark of undifferentiated spermatogonia and is required for maintenance of male germline stem cells
}

\author{
Matthew F. Pech, ${ }^{1,2,7}$ Alina Garbuzov, ${ }^{1,3,7}$ Kazuteru Hasegawa, ${ }^{1}$ Meena Sukhwani ${ }^{4,5}$ Ruixuan J. Zhang, ${ }^{1}$ \\ Bérénice A. Benayoun, ${ }^{3}$ Stephanie A. Brockman, ${ }^{1}$ Shengda Lin, ${ }^{1}$ Anne Brunet, ${ }^{3}$ Kyle E. Orwig, ${ }^{4,5}$ \\ and Steven E. Artandi ${ }^{1,2,6}$ \\ ${ }^{1}$ Department of Medicine, Stanford University School of Medicine, Stanford, California 94305, USA; ${ }^{2}$ Cancer Biology Program, \\ Stanford University School of Medicine, Stanford, California 94305, USA; ${ }^{3}$ Department of Genetics, Stanford University, \\ California 94305, USA; ${ }^{4}$ Department of Obstetrics, Gynecology, and Reproductive Sciences, University of Pittsburgh School of \\ Medicine, Pittsburgh Pennsylvania 15213, USA; ${ }^{5}$ Magee-Womens Research Institute, Pittsburgh, Pennsylvania 15213, USA; \\ ${ }^{6}$ Department of Biochemistry, Stanford University School of Medicine, Stanford, California 94305, USA
}

Telomerase inactivation causes loss of the male germline in worms, fish, and mice, indicating a conserved dependence on telomere maintenance in this cell lineage. Here, using telomerase reverse transcriptase (Tert) reporter mice, we found that very high telomerase expression is a hallmark of undifferentiated spermatogonia, the mitotic population where germline stem cells reside. We exploited these high telomerase levels as a basis for purifying undifferentiated spermatogonia using fluorescence-activated cell sorting. Telomerase levels in undifferentiated spermatogonia and embryonic stem cells are comparable and much greater than in somatic progenitor compartments. Within the germline, we uncovered an unanticipated gradient of telomerase activity that also enables isolation of more mature populations. Transcriptomic comparisons of Tert ${ }^{\text {High }}$ undifferentiated spermatogonia and Tert $^{\text {Low }}$ differentiated spermatogonia by RNA sequencing reveals marked differences in cell cycle and key molecular features of each compartment. Transplantation studies show that germline stem cell activity is confined to the $\mathrm{Tert}^{\text {High }}$ cKit $^{-}$population. Telomere shortening in telomerase knockout strains causes depletion of undifferentiated spermatogonia and eventual loss of all germ cells after undifferentiated spermatogonia drop below a critical threshold. These data reveal that high telomerase expression is a fundamental characteristic of germline stem cells, thus explaining the broad dependence on telomerase for germline immortality in metazoans.

[Keywords: aging; germline stem cells; spermatogenesis; telomerase; telomeres]

Supplemental material is available for this article.

Received September 11, 2015; revised version accepted October 27, 2015.

The germline and the soma face fundamentally different challenges in preserving genetic integrity. Somatic stem cells need to only maintain genome function for the reproductive life of the animal, whereas germline stem cells (GSCs) must ensure that the gametes and resulting embryos can successfully contribute to subsequent generations (Smelick and Ahmed 2005; Cinalli et al. 2008). One aspect of genome integrity that is markedly different between the germline and the soma is the maintenance of telomeres, the nucleoprotein caps that protect chromosome ends (Palm and de Lange 2008). Whereas telomeres shorten with aging in a variety of somatic tissues, telo-

\footnotetext{
${ }^{7}$ These authors contributed equally to this work. Corresponding author: sartandi@stanford.edu

Article published online ahead of print. Article and publication date are online at http://www.genesdev.org/cgi/doi/10.1101/gad.271783.115.
}

meres are maintained with advancing age in sperm /de Lange et al. 1990; Allsopp et al. 1992; Zalenskaya and Zalensky 2002; Baird et al. 2003). Challenges in detecting telomerase, the enzyme that synthesizes telomere repeats, have precluded an understanding of the mechanisms governing this dichotomy between germline and somatic telomere dynamics.

Telomeres shorten with each cell division due to incomplete replication of the chromosome ends. After an extended lag period during which telomeres continue to shorten, the protective function of telomeres is lost at a

\footnotetext{
(C) 2015 Pech et al. This article is distributed exclusively by Cold Spring Harbor Laboratory Press for the first six months after the full-issue publication date (see http://genesdev.cshlp.org/site/misc/terms.xhtml). After six months, it is available under a Creative Commons License (Attribution-NonCommercial 4.0 International), as described at http:// creativecommons.org/licenses/by-nc/4.0/.
} 
subset of chromosome ends, leading to propagation of a DNA damage response that induces senescence or cell death (d'Adda di Fagagna et al. 2003; Takai et al. 2003). Telomerase counters this process by adding telomeric repeats to chromosome ends, a process that is important for long-term cell viability in tissue progenitor cells and cancers (Artandi and DePinho 2010). In vivo, telomere maintenance by telomerase is broadly required for proper homeostasis of proliferative tissues (Lee et al. 1998). In humans, even modest reductions in telomerase levels can result in a collection of somatic tissue failure phenotypes, including aplastic anemia, pulmonary fibrosis, and liver cirrhosis (Batista et al. 2011; Armanios and Blackburn 2012).

Complete genetic inactivation of telomerase in model organisms has implicated the male germline as the most telomerase-dependent tissue. Telomere shortening in mice or fish lacking telomerase causes infertility and the eventual loss of male germ cells (Lee et al. 1998; Henriques et al. 2013; Harel et al. 2015). Inactivation of telomerase in worms leads to infertility and a loss of male germ cells as telomeres shorten (Meier et al. 2006). The loss of germ cell cellularity in telomerase-deficient mouse strains is caused by apoptosis triggered by telomere dysfunction (Lee et al. 1998; Hemann et al. 2001). However, the specific cellular compartment adversely affected by telomerase loss is unknown. Previous studies suggested that a telomere surveillance mechanism recognized short telomeres and induced apoptosis at the onset of meiosis (Hemann et al. 2001). The mechanisms underlying the exquisite dependence on telomere maintenance by the germline would be aided by understanding telomerase expression patterns in the male germ cell lineage. Other than mature sperm, every major germ cell population has been previously proposed as the principal cell type expressing telomerase (Zalenskaya and Zalensky 2002).

Generation of sperm is fueled by male GSCs, which self-renew and generate differentiated progeny throughout life (Spradling et al. 2011). In mice, male GSCs reside in a population of mitotic cells, termed undifferentiated spermatogonia based on their undifferentiated histological appearance (de Rooij and Russell 2000). These rare cells on the basement membrane of seminiferous tubules are found as single cells, in pairs, and in chains of four to 16 cells (termed A-single, A-paired, and A-aligned, respectively). Incomplete cytokinesis with cell division in this compartment results in elongating cell syncytia. Undifferentiated spermatogonia give rise to differentiated spermatogonia, which are marked by expression of the cell surface receptor cKit (Schrans-Stassen et al. 1999). Differentiated spermatogonia undergo a series of transit-amplifying divisions before entering meiosis. During each cycle of spermatogenesis, the vast majority of spermatogonia migrate luminally to enter meiosis and eventually leave the testis as spermatozoa.

Although undifferentiated spermatogonia have not been purified as a population, several lines of evidence indicate that this population harbors the GSCs. Undifferentiated spermatogonia mature according to a cycle that culminates in the production of new (type A1) differentiated spermatogonia. Histological data indicate that only short chain undifferentiated spermatogonia persist into a new cycle, whereas longer chain spermatogonia differentiate, suggesting that GSCs reside in this short chain population (Huckins 1971; Oakberg 1971; de Rooij 1973). Enrichment for certain cell markers such as Thy1, a6-integrin, Oct4, Id4, Pax7, and others, coupled with transplantation, showed that cells within the undifferentiated spermatogonia population possess stem cell activity (Shinohara et al. 1999; Ohbo et al. 2003; Aloisio et al. 2014; Chan et al. 2014). Lineage tracing of cells expressing GDNF family receptor a1 (GFR $\alpha 1$ ), which marks many of the short chain undifferentiated spermatogonia, yields long-term labeling of the germ cell lineage in mice (Nakagawa et al. 2010; Hara et al. 2014). Together, these findings indicate that GSCs are located within the undifferentiated spermatogonia pool.

Telomerase reverse transcriptase (Tert) transcription represents a primary point of control of telomerase levels (Meyerson et al. 1997). To understand where telomerase is expressed within the male germline, we engineered a Tert promoter knock-in mouse strain in which a fluorescent reporter protein is expressed from the endogenous Tert promoter. We used this reporter strain to determine which populations express telomerase within the male germline and exploited this approach to isolate and study phenotypically defined populations of spermatogonia. These advances allow comparisons of telomerase activity between germline progenitor cells and somatic progenitor cells. We leveraged these techniques to determine the underlying reason for germline dependence on telomerase across metazoans, with important implications for understanding germline immortality.

\section{Results}

Reporter expression from a Tert promoter knock-in accurately reflects telomerase activity in both pluripotent and differentiating embryonic stem (ES) cells

Based on the importance of telomerase in the germline across many species, we hypothesized that high Tert expression may characterize self-renewing cells in the male germline. To test this idea, we engineered a Tert promoter reporter knock-in mouse strain by inserting the red fluorescent protein (RFP) TdTomato at the initiating methionine within the first exon of Tert (Fig. 1A). Mouse ES (mES) cells were targeted by homologous recombination, and correct clones were identified by long-range PCR and Southern blot (Supplemental Fig. 1A,B). Tomato expression was evident in Tert ${ }^{\text {Tomato/+ }} \mathrm{mES}$ cultures by epifluorescence (Fig. 1B), and flow cytometry indicated homogenous expression of Tomato in $>98 \%$ of the cells, with clear signal separation from autofluorescence in parental control mES cultures (Fig. 1C). To examine the relationship between telomerase levels and the pluripotent state, TERT $T^{\text {Tomato/+ }}$ mES cells were targeted a second time to insert a green fluorescent protein (GFP) reporter at the OCT4 locus (Supplemental Fig. 1C-E). Fluorescence- 
Pech et al.
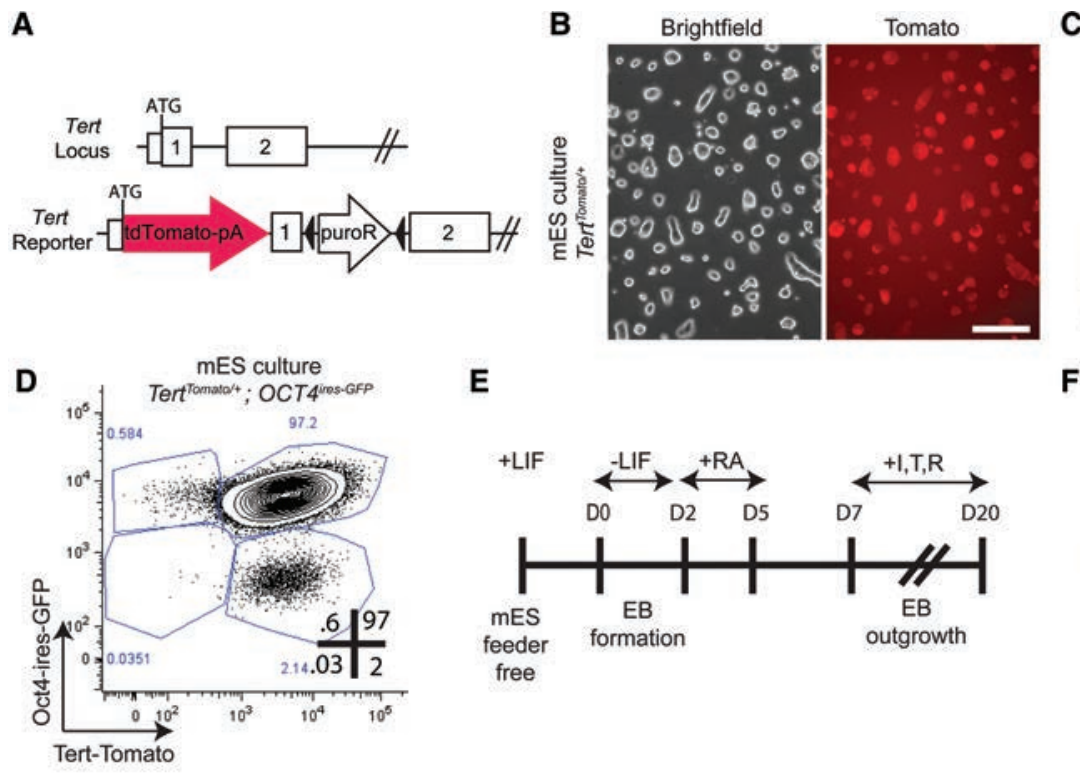

$\mathbf{E}$

$\mathbf{F}$
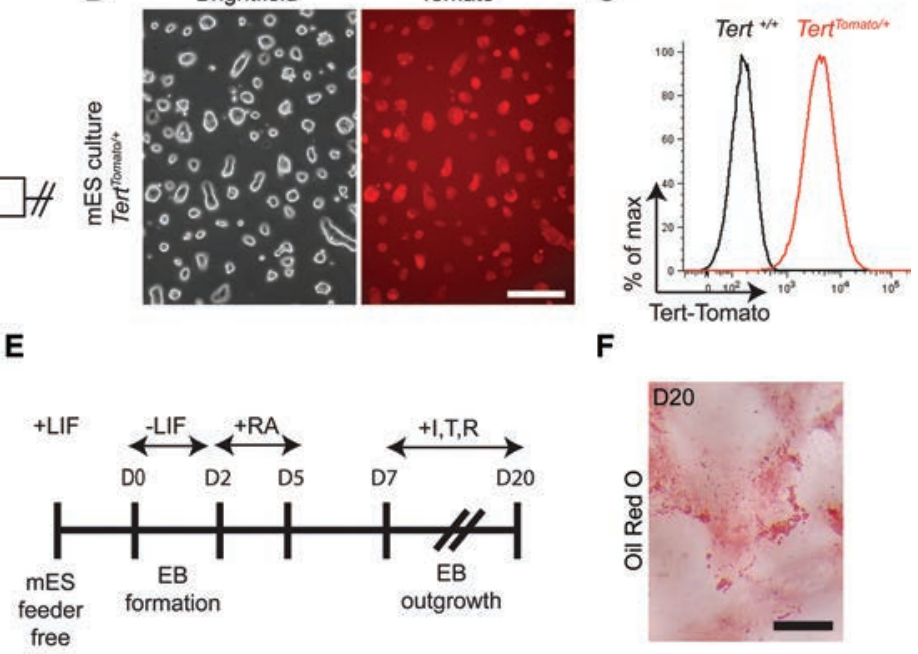

G
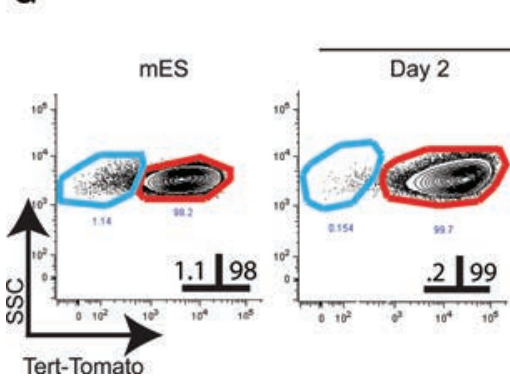

Forced Differentation

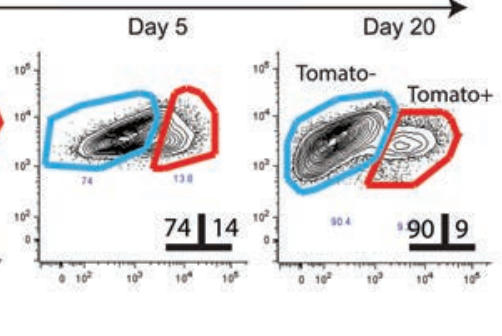

H

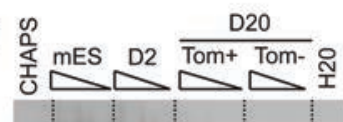

Figure 1. A Tert promoter knock-in reporter accurately reflects telomerase activity in both pluripotent and differentiating ES cells. $(A)$ Generation of a knock-in transcriptional Tert reporter. TdTomato was inserted at the initiating methionine of Tert, with a floxed resistance cassette placed into the first intron. (B) Phase contrast and epifluorescent microscopy of Tert-Tomato reporter in Tert ${ }^{\text {Tomato/+ }} \mathrm{mES}$ cells grown in LIF/2i conditions. Bar, $200 \mu \mathrm{m}$. (C) Expression of Tert-Tomato reporter in Tert ${ }^{\text {Tomato/+}} \mathrm{mES}$ cells grown in LIF/2i, quantified by FACS. Untargeted parental mES cells are shown in black. Results were consistent across independently targeted clones. $(D)$ Expression of fluorescent reporter genes by FACS in doubly targeted Tert ${ }^{\text {Tomato/+ }}$ Oct $4^{\text {ires-EGFP/+ }}$ mES cells grown in LIF/2i conditions. Gates were drawn relative to parental and singly targeted mES cells. $(E)$ Schema for in vitro differentiation of mES cells to an adipogenic fate. (EB) Embryoid body; (RA) retinoic acid; (I,T,R) insulin, triiodothyronine, and rosiglitazone. (F) Oil-Red-O staining of mES cells at day 20 of differentiation. Bar, $500 \mu \mathrm{m}$. $(G)$ Fluorescent reporter expression by FACS in Tert ${ }^{\text {Tomato/+ }} \mathrm{mES}$ cells during adipogenic differentiation. Gates were drawn based on the background fluorescence of untargeted parental mES cells. The percent of events in each gate is shown. (SSC) Side scatter. $(H)$ Telomerase activity measured by telomere repeat amplification protocol (TRAP) in populations shown in $G$. CHAPS and $\mathrm{H}_{2} 0$ represent buffer-only negative controls. TRAP reactions were programmed with 3000 or 1000 FACS-sorted cell equivalents.

activated cell sorting (FACS) analysis revealed a direct correlation between Tert and Oct 4 expression, with $>97 \%$ of cells expressing both reporters in undifferentiated $\mathrm{mES}$ cultures (Fig. 1D).

Tert ${ }^{\text {Tomato } /+} \mathrm{mES}$ cells were differentiated in vitro to determine whether Tomato levels accurately reflected endogenous Tert regulation during ES cell differentiation. To direct ES cells toward an adipogenic fate, LIF was withdrawn from the mES cultures, followed by exposure of embryoid bodies to retinoic acid and culminating with culture of the aggregates in proadipogenic hormones (Fig. 1E,F). Reporter expression and telomerase enzymatic activity were coordinately down-regulated during the differentiation protocol (Fig. 1G,H). By day 20 of the protocol, $90 \%$ of cells were negative for Tomato expression by FACS, and these cells lacked telomerase activity as measured by the telomere repeat amplification protocol (TRAP) assay (Fig. 1G,H). The remaining $10 \%$ of cells expressed significantly lower levels of Tomato by FACS and telomerase activity by TRAP compared with the undifferentiated $\mathrm{mES}$ cell population (Fig. 1G,H). Importantly, this subpopulation of cells still expressing telomerase was readily isolated from the majority of cells, which lacked telomerase expression. Therefore, this approach may have similar utility in isolating telomerase-expressing cells in vivo. Taken together, these data show that the Tert-Tomato knockin accurately reflects endogenous telomerase expression in undifferentiated $\mathrm{mES}$ cells and during $\mathrm{mES}$ cell differentiation. 


\section{High telomerase levels are a hallmark} of undifferentiated spermatogonia

To identify telomerase-positive cells in vivo, Tert ${ }^{\text {Tomato/+ }}$ mice were generated by blastocyst injection. Tert ${ }^{\text {Tomato/+ }}$ mice were healthy, fertile, and born at the expected Mendelian frequencies. During mouse embryogenesis, the germline is specified with the development of primordial germ cells (PGCs), which migrate to the gonadal ridge and colonize the gonads (Saitou and Yamaji 2012). After birth, the gonocytes attach to the basement membrane of the seminiferous tubules and give rise to the adult spermatogonia. Gonocytes are marked by expression of the pluripotency factor Oct4 and can be identified using a transgenic Oct4-GFP reporter strain (Yeom et al. 1996). We first analyzed Tert reporter expression in neonatal testis in compound $\mathrm{Tg}(\mathrm{Oct} 4-\triangle P E-G F P)^{+}$; Tert Tomato/+ $^{\text {mice }}$ and used whole-mount immunofluorescence of seminiferous tubules with antibodies to RFP and GFP to assess activity of the Tert and Oct4 promoters, respectively. In postnatal day 6 testes, all juvenile spermatogonia, marked by Oct4-GFP, strongly expressed Tert-Tomato (Fig. 2A). Flow cytometry on disaggregated postnatal day 6 testis from $\mathrm{Tg}(\mathrm{Oct} 4-\triangle P E-G F P)^{+}$; Tert ${ }^{\text {Tomato/+ }}$ mice confirmed coexpression of the Tert and Oct4 promoters at the single-cell level (Fig. 2B; Supplemental Fig. 2A). These data show that the male germline lineage is founded by cells that express both Tert and Oct4.

Adult spermatogonia are traditionally divided into undifferentiated and differentiated subtypes (Fig. 2C). Undifferentiated spermatogonia expressing promyelocytic leukemia zinc finger (PLZF) are thought to contain the vast majority of GSCs, whereas differentiated $\mathrm{cKit}^{+}$spermatogonia generally lack self-renewal potential (Shinohara et al. 1999, 2000; Buaas et al. 2004; Costoya et al. 2004; Nakagawa et al. 2010). In adult seminiferous tubules, immunostaining to determine Tert promoter activity identified rare, bright Tomato $^{+}$cells occurring as single cells, paired cells, or chains of cells along the basement membrane. Costaining revealed a nearly perfect correlation between Tomato-high cells and PLZF, indicating that undifferentiated spermatogonia exhibit the strongest
A

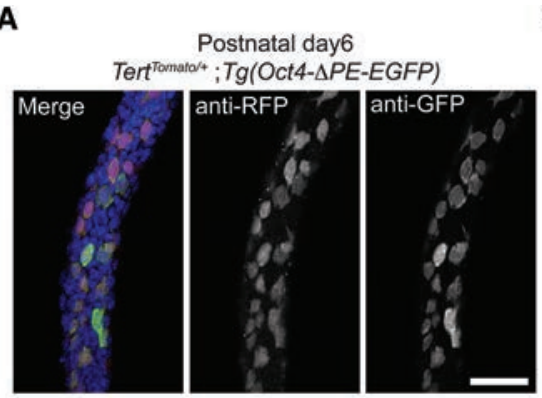

D

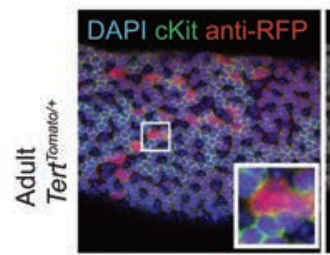

E

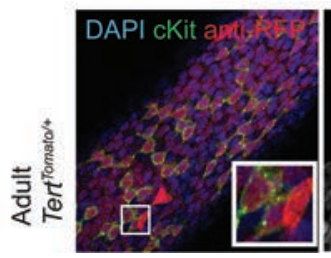

B
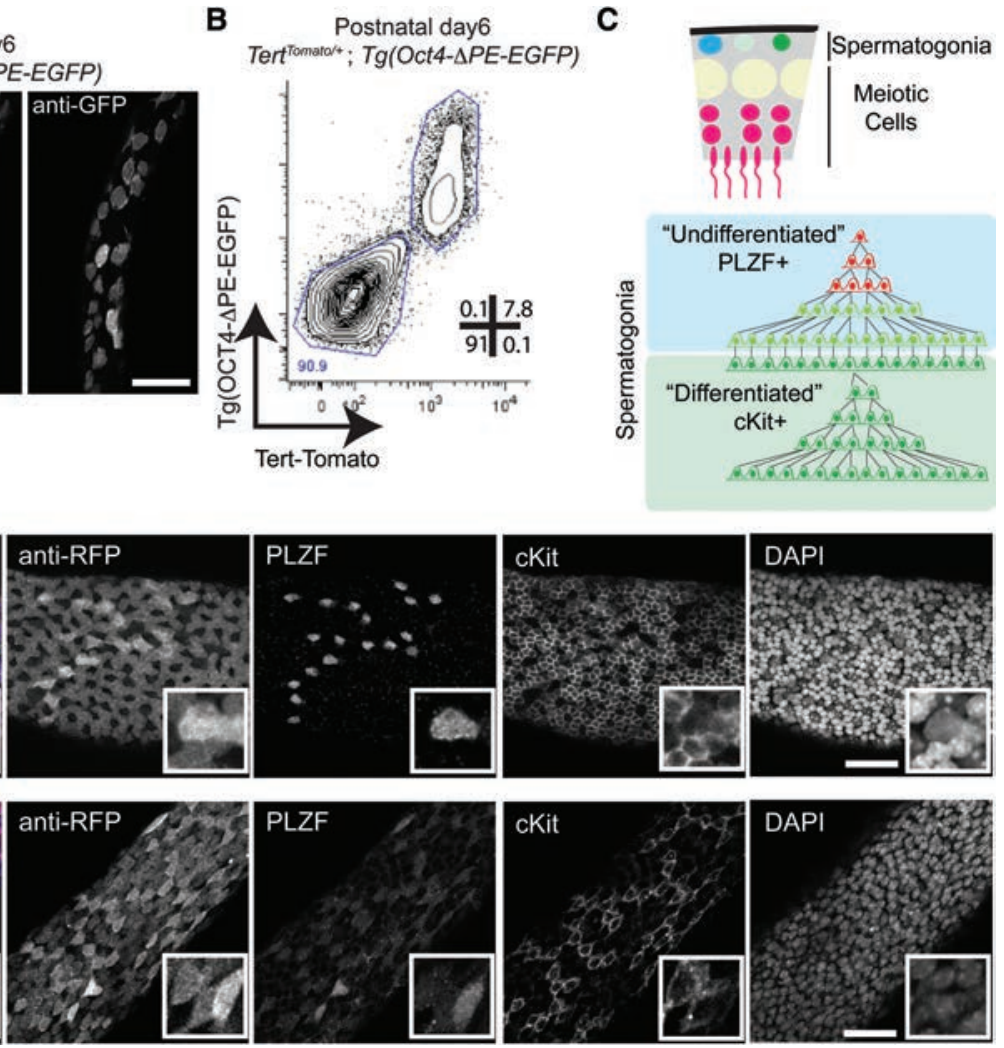

Figure 2. High telomerase levels are a hallmark of undifferentiated spermatogonia. $(A)$ Whole-mount analysis of seminiferous tubules from postnatal day 6 Tert ${ }^{\text {Tomato/+ }} \mathrm{Tg}(\mathrm{Oct} 4-\triangle P E-G F P)$ mice, immunostained with anti-RFP and anti-GFP antibodies. Bar, $50 \mu \mathrm{m}$. (B) FACS analysis of dissociated tubules from postnatal day 6 Tert ${ }^{\text {Tomato/+ }} \mathrm{Tg}$ (Oct4- $\left.\triangle P E-G F P\right)$ mice. Cells were gated by scatter and DAPI exclusion. Gates were drawn based on the fluorescence properties of wild-type and single-heterozygous mice. (C) Model of adult spermatogenesis. Mitotic spermatogonia are found along the basement membrane of the seminiferous tubules and are generally divided into undifferentiated $\mathrm{PLZF}^{+}$(promyelocytic leukemia zinc finger-positive) and differentiated cKit ${ }^{+}$populations. $(D, E)$ Whole-mount analysis of adult seminiferous tubules immunostained for PLZF, cKit, and RFP in Tert Tomato/+ seminiferous tubules. Bar, $50 \mu \mathrm{m}$. Of the PLZF ${ }^{+}$cells, $99.7 \% \pm 0.1 \%$ were Tert-Tomato ${ }^{+}(n=2270$ cells; $n=6$ mice $)$. Of the cKit $^{+}$cells, $100 \% \pm 0 \%$ were Tert-Tomato ${ }^{+}(n=4 \mathrm{mice} n=2600$ cells). 
Tert promoter activity (Fig. 2D; Supplemental Fig. 2B for wild-type staining controls). We also detected a second population of cells expressing Tert-Tomato but at a lower level. These cells were $\mathrm{cKit}^{+}$differentiated spermatogonia, which fill the basement membrane and surround the TERT ${ }^{\text {high }}$ cells in specific stages of the spermatogonial cycle (Fig. 2D). Less mature differentiated spermatogonia, which are found in chains and contain punctate foci of cKit expression (Nakagawa et al. 2010), showed higher Tert-Tomato expression, with levels closer to those in undifferentiated cells (Fig. 2E). These data show that high Tert promoter activity is a characteristic of undifferentiated spermatogonia and that the Tert promoter is down-regulated upon maturation to the differentiated spermatogonial state.

\section{High telomerase activity in undifferentiated spermatogonia and a telomerase gradient in the germ cell lineage}

The pattern of Tomato expression in whole mounts suggested that several adult spermatogonial subtypes could be isolated based on their discrete levels of Tert promoter activity. To test this hypothesis, we dissociated seminiferous tubules from Tert ${ }^{\text {Tomato/+ }}$ mice into viable single cells and subjected them to FACS. FACS analysis based on Tomato expression and cell size alone was sufficient to resolve germ cells into five distinct populations $\left(\right.$ Tert $^{\mathrm{Neg} 1}$, Tert $^{\text {Neg2 }}$, Tert ${ }^{\text {Low-Meiotic }}$, Tert ${ }^{\text {Low }}$, and Tert ${ }^{\text {High }}$ ) (Fig. 3A; Supplemental Fig. 3A,B). To understand whether Tomato signal intensity correlated with telomerase activity, we
A

C


$\mathbf{F}$

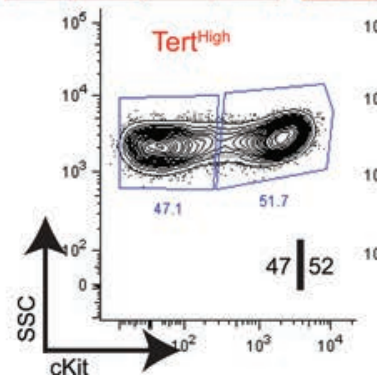

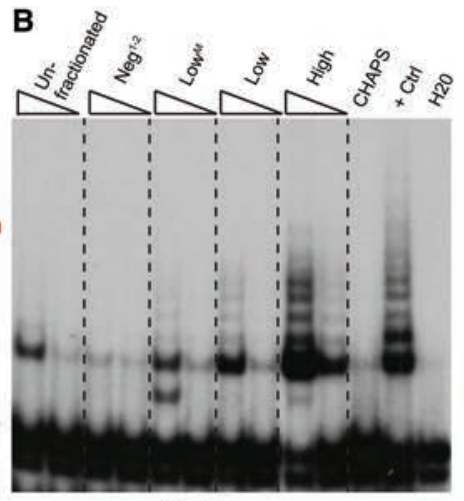

D 1007
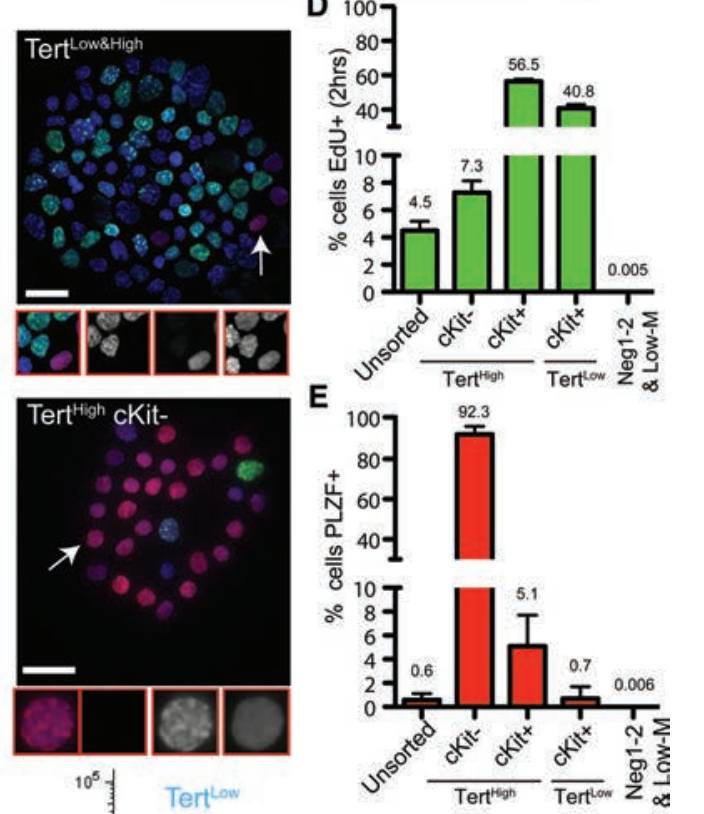

Figure 3. Isolation and characterization of the Tert $^{\text {High }}$ undifferentiated spermatogonial pool. $(A)$ FACS analysis of the Tert ${ }^{\text {Tomato/+ }}$ testis in the adult mouse; Tomato fluorescence versus forward scatter (FSC) in live, single cells. Populations colored in blue expressed below background levels of Tert-Tomato (see Supplemental Fig. S5). Representative results from at least $n=50$ mice are shown. $(B)$ Telomerase activity by TRAP assay using FACS-isolated cell populations shown in $A$. TRAP reactions were programmed with 3000 or 750 cell equivalents. Results representative of three independent experiments are shown. $(C)$ 5'-ethynyl-2'-deoxyuridine (EdU) and PLZF staining in FACS-isolated populations after cytospin. Mice received a 2-h EdU pulse prior to analysis. Bar, $25 \mu \mathrm{m}$. Regions highlighted by arrows are shown in higher magnification. $(D)$ Quantification of EdU incorporation from $C(n \geq 5$ mice; $n=900-21,000$ cells). The error bar shows SEM. (E) Quantification of anti-PLZF immunofluorescence from $C(n \geq 5$ mice; $n=3000$ 21,000 cells). The error bar shows SEM. (F) Sorting strategy for isolating undifferentiated and differentiated spermatogonia. Tert ${ }^{\text {High }}$ and Tert ${ }^{\text {Low }}$ fractions were discernible when TERT-Tomato expression was plotted against cell side scatter (SSC) in live singlet cells. The Tert ${ }^{\text {High }}$ fraction was an equal mixture of $\mathrm{cKit}^{+}$ and $\mathrm{cKit}^{-}$cells, whereas the Tert ${ }^{\mathrm{Low}}$ fraction was a $>90 \%$ population of $\mathrm{cKit}^{+}$cells. Representative results from at least 50 mice are shown. 
isolated each population by FACS and used extracts from equal numbers of purified cells to program TRAP reactions (Fig. 3B). Neg1 and Neg2 populations lacked both Tomato expression by FACS and telomerase activity by TRAP. In cells expressing Tomato, there was a direct correlation between Tomato levels and telomerase activity, with reporter fluorescence and telomerase enzyme activity increasing in the following order: Tert ${ }^{\text {Low-Meiotic }}$ Tert $^{\text {Low }}$, and Tert ${ }^{\text {High }}$. Tert ${ }^{\text {High }}$ cells were brightest for Tomato expression and exhibited the highest TRAP activity - approximately fourfold greater than Tert ${ }^{\text {Low }}$ cells. Thus, a gradient of telomerase expression exists in the germ cell lineage.

To identify the mitotic spermatogonia in our purified populations, we performed 5'-ethynyl-2'-deoxyuridine (EdU) injection in vivo followed by FACS and cytospin. All EdU ${ }^{+}$cells were found in the Tert ${ }^{\text {Low }}$ and Tert ${ }^{\text {High }}$ populations (Fig. 3C,D). Immunostaining for PLZF expression in purified cells after cytospin revealed that all $\mathrm{PLZF}^{+}$cells were also found in these fractions. Conversely, neither mitotic nor $\mathrm{PLZF}^{+}$cells were detected within the pooled $\mathrm{Tert}^{\mathrm{Neg} 1}$, Tert ${ }^{\mathrm{Neg} 2}$, or Tert $^{\text {Low-Meiotic }}$ populations $(6 \times$ $10^{-3} \pm 0.02 \%$ PLZF $^{+}$cells; $5 \times 10^{-3} \pm 0.01 \%$ EdU $^{+}$cells) (Fig. 3C,D). Examination of nuclear morphology showed that Tert $^{\mathrm{Neg} 1}$ and $\mathrm{Tert}^{\mathrm{Neg} 2}$ represented a $92 \% \pm 5 \%$ pure population of round spermatids and an $80 \% \pm 10 \%$ pure population of elongating spermatids, respectively $(n=3-4$ mice) (Supplemental Fig. 3C). Cells in Tert ${ }^{\text {Low-Meiotic }}$ were larger in size, expressed low levels of telomerase, and stained positive for the synaptonemal complex proteins 1 and $3(\mathrm{SCP} 1 / 3)$, indicating that this population was an $81 \% \pm 17 \%$ pure population of cells in meiosis I ( $n=3$ mice; main contaminant was round spermatids) (Supplemental Fig. 3D). Mature sperm isolated from the epididymis did not express Tomato (Supplemental Fig. 3E).

Whole-mount analysis suggested that the undifferentiated $\mathrm{PLZF}^{+}$spermatogonia had a distinctly higher level of Tert-Tomato reporter activity than the differentiated $\mathrm{cKit}^{+}$spermatogonia. To understand more broadly the location of undifferentiated spermatogonia in our purified populations, we isolated Tert ${ }^{\text {High }}$ and Tert ${ }^{\text {Low }}$ cells and analyzed expression of cKit in these populations. Tert ${ }^{\text {High }}$ cells contained a similar number of $\mathrm{cKit}^{+}$and $\mathrm{cKit}^{-}$cells, whereas $>90 \%$ of Tert $^{\text {Low }}$ cells were $\mathrm{cKit}^{+}$(Fig. 3F). Cytospin followed by immunostaining revealed that $\mathrm{PLZF}^{+}$ cells were found almost exclusively in the $\mathrm{Tert}^{\mathrm{High}} \mathrm{cKit}^{-}$ fraction, which represented a nearly pure population of PLZF $^{+}$cells $(93 \% \pm 5 \% ; n=5$ mice; $n=5200$ cells counted) (Fig. 3C-E). Meiotic cell contamination was negligible. Assessment of proliferation by in vivo EdU labeling revealed that Tert $^{\text {High }}$ cKit $^{-}$cells had an S-phase fraction of $7.0 \% \pm 0.9 \%$ (Fig. 3C,D). These data indicate that nearly all undifferentiated spermatogonia are found within the Tert $^{\text {High }}$ cKit $^{-}$population.

The remaining Tert ${ }^{\text {High }}$ and Tert $^{\text {Low }}$ spermatogonial populations represented $\mathrm{cKit}^{+}$differentiated spermatogonia. Cytospin analysis revealed that these $\mathrm{cKit}^{+}$fractions contained very few PLZF ${ }^{+}$cells (Fig. 3C-E). These cKit ${ }^{+}$ cells showed the heterochromatic nuclear morphology typical of differentiated spermatogonia cells; in contrast, Tert ${ }^{\text {High }}$ cKit $^{-}$cells had the homogenous chromatin pattern characteristic of undifferentiated spermatogonia (Fig. 3C). Differentiated spermatogonia were much more proliferative than their undifferentiated counterparts, with $40 \%-60 \%$ of cells EdU ${ }^{+}$after a 2 -h pulse (Fig. 3D). $\mathrm{Tert}^{\mathrm{High}} \mathrm{cKit}^{+}$cells were distinct from Tert ${ }^{\mathrm{Low}} \mathrm{cKit}^{+}$cells in many respects. Tert ${ }^{\text {High }}$ cKit $^{+}$cells were less abundant and larger in size and expressed higher cKit and TdTomato levels than Tert ${ }^{\text {Low }}$ cKit $^{+}$cells. Furthermore, most $(68 \% \pm 1.5 \%)$ Tert $^{\text {High }}$ cKit $^{+}$cells expressed spermatogogenesis- and oogenesis-specific basic helix-loop-helix 1 (SOHLH1), a transcription factor expressed in the A1-A4 and Int subtypes of differentiated cells (Suzuki et al. 2012), whereas $\mathrm{SOHLH1}^{+}$cells were rare $(3.6 \% \pm$ $3.7 \%$ ) in the $\mathrm{Tert}^{\mathrm{Low}} \mathrm{cKit}^{+}$fraction (Supplemental Fig. 3F).

Altogether, these results provide strong evidence for the successful isolation of undifferentiated and differentiated spermatogonia based on Tert promoter activity and cKit expression. Importantly, these populations correspond to those identified by whole-mount immunostaining (Fig. 2), providing a consistent view of spermatogonial maturation in sorted cells and intact tissue. The ability to purify these discrete spermatogonial populations enabled subsequent molecular and functional studies.

\section{A molecular signature of the undifferentiated spermatogonial state}

To understand molecular differences between the Tert ${ }^{\text {High }}$ $\mathrm{cKit}^{-}$undifferentiated spermatogonia and Tert ${ }^{\text {Low }} \mathrm{cKit}^{+}$ differentiated spermatogonia, we performed transcriptional profiling on these two populations using next-generation sequencing. Unsupervised hierarchical clustering was used to validate biological replicates (Supplemental Fig. 4A). Differential expression analysis identified 3578 genes significantly up-regulated in $\mathrm{Tert}^{\mathrm{High}} \mathrm{cKit}^{-}$cells and 1872 genes significantly up-regulated in Tert ${ }^{\text {Low }}$ cKit $^{+}$cells $(1 \%$ false discovery rate [FDR] and twofold change cutoff) (Fig. 4A; Supplemental Table S1). Tert ${ }^{\text {Low }}$ $\mathrm{cKit}^{+}$cells showed strong expression of many prodifferentiation markers, including cKit, Epcam, Stra8, Scp1, and Scp3. In contrast, the most significantly up-regulated genes in $\mathrm{Tert}^{\mathrm{High}} \mathrm{cKit}^{-}$cells were highly enriched for known markers, and regulators of undifferentiated spermatogonia, including genes such as Plzf, Lin28a, Gfra1, Ret, Sall1, Foxo1/3, Cdh1, Itga6, Ngn3, Nanos3, and Utf1, ranked highly (Shinohara et al. 1999; Nakagawa et al. 2010; Phillips et al. 2010; Goertz et al. 2011). This data set contains many new potential markers of undifferentiated spermatogonia. We validated two such markers -Syndecan4 (SDC4) and Musashi2 (MSI2) — at the protein level by whole-mount microscopy and/or FACS (Sdc4, 58-fold change, $q=2.8 \times 10^{-129} ;$ Msi2, 4.05-fold change, $q=4.06 \times 10^{-34}$ ) (Fig. 4B,C; Supplemental Fig. 4B-D). Expression of each of these proteins was detected in PLZFpositive but not PLZF-negative cells, consistent with their specific expression in undifferentiated spermatogonia. This approach was also useful for discovering new markers of differentiated spermatogonia. Activated leukocyte 
A



PLZF MSI2 DAPI $\quad$ MSI2

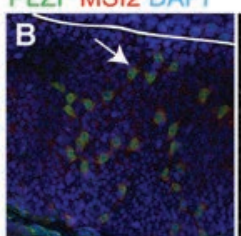

PLZF SDC4 DAP|

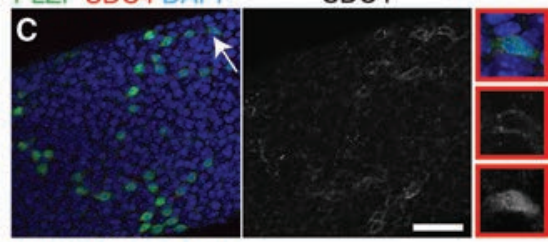

PLZF ALCAM DAPI

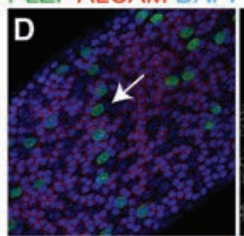

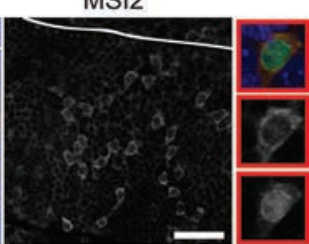

SDC4

ALCAM



E

\begin{tabular}{lcccc}
\hline \multicolumn{1}{c}{ Gene Sets Enriched } & $\begin{array}{c}\text { Genes } \\
\text { overlapping }\end{array}$ & Source & nES & FDR q-value \\
\hline $\begin{array}{l}\text { Enriched in Tert'igh cKit- } \\
\text { BCAT_GDS748_UP }\end{array}$ & 35 & C6: oncogenic signatures & 1.81 & 0.02 \\
AKT_UP_MTOR_DN.V1_UP & 133 & C6: oncogenic signatures & 1.72 & 0.01 \\
MEK_UP.V1_UP & 159 & C6: oncogenic signatures & 1.65 & 0.01 \\
V\$FOXO1_02 & 135 & C3: motif gene sets & 1.87 & 0.01 \\
Enriched in Tert & & & & \\
ISHIDA_CKit+ & 47 & C2: curated gene sets & -2.74 & 0.00 \\
VSE2F1DP1_01 & 182 & C3: motif gene sets & -2.37 & 0.00 \\
MEIOTIC_CELL_CYCLE & 29 & C5: GO gene sets & -2.21 & 0.005 \\
MEIOSISI & 16 & C5: GO gene sets & -1.99 & 0.02 \\
& & & & \\
\hline
\end{tabular}

Figure 4. Transcriptional landscape of adult spermatogonial subtypes. $(A)$ Volcano plot of expression profiles comparing Tert ${ }^{\text {High }} \mathrm{cKit}^{-}$ with Tert ${ }^{\mathrm{Low}} \mathrm{cKit}^{+}$cells. Genes whose expression significantly differs between the populations are labeled in red (FDR threshold $1 \%$, twofold change threshold). Genes in blue are undifferentiated (A-undiff) markers from the literature. Genes in green are differentiated-biased markers from the literature. The entire list of differentially expressed genes is reported in Supplemental Table S1. $(B)$ Whole-mount analysis of adult seminiferous tubules stained for MSI2 and PLZF. Bar, $50 \mu \mathrm{m}$. (C) Whole-mount analysis of adult seminiferous tubules stained for SDC4 and PLZF. Bar, $50 \mu \mathrm{m}$. $(D)$ Whole-mount analysis of adult seminiferous tubules stained for ALCAM and PLZF. Bar, $50 \mu \mathrm{m}$. B-D represent multiple independent mice. (E) Gene set enrichment analysis (GSEA) of genes up-regulated in $\mathrm{Tert}^{\mathrm{High}} \mathrm{cKit}^{-}$or Tert ${ }^{\mathrm{Low}} \mathrm{cKit}^{+}$cells against a database of curated gene sets. Selected significant signatures are shown. The entire GSEA is reported in Supplemental Table S1.

adhesion molecule (ALCAM) was one of the top genes upregulated in $\mathrm{Tert}^{\mathrm{Low}} \mathrm{cKit}^{+}$cells versus Tert ${ }^{\mathrm{High}} \mathrm{cKit}^{-}$cells (14.6-fold change, $\left.q=2.7 \times 10^{-24}\right)$. Whole-mount staining showed that ALCAM was expressed in a subset of the most mature $\mathrm{cKit}^{+}$cells and was not expressed in PLZFpositive cells (Fig. 4D; Supplemental Fig. 4E-G).

A comparison of our Tert ${ }^{\text {High }}$ cKit $^{-}$gene signature data set with those found in the Molecular Signatures Database (MSigDB) using gene set enrichment analysis (GSEA) (Subramanian et al. 2005) highlighted several signaling pathways important for the identity of undifferentiated spermatogonia (Fig. 4E; Supplemental Table S2). A signature of activated Wnt signaling had the highest enrichment score for the $\mathrm{Tert}^{\text {High }} \mathrm{cKit}^{-}$population, suggesting a role for this pathway in this population of stem and progenitor cells. Genes up-regulated in Tert ${ }^{\text {High }}$ $\mathrm{cKit}^{-}$cells were also significantly enriched for multiple gene sets related to active JNK, MEK, or AKT, oncogenic K-ras, and suppression of PTEN (Fig. 4E; Supplemental Table S2). PI3K/AKT signaling and Ras/MEK signaling are known to play important roles downstream from GFRal/Ret, central growth factor receptors in spermatogonia, with inhibition of PI3K/AKT signaling leading to male sterility (Lee et al. 2007, 2009; Goertz et al. 2011). Activation of the PI3K/AKT pathway controls activity of the FOXO proteins by causing their translocation to the nucleus. FOXO proteins are specifically expressed in undifferentiated spermatogonia, and their deletion causes stem cell loss and male sterility (Goertz et al. 2011). Consistent with this signature of PI3K/AKT 
activation, analysis for cis-regulatory motifs associated with the $\mathrm{Tert}^{\mathrm{High}} \mathrm{cKit}^{-}$gene list revealed a significant FOXO family signature, with multiple data sets of genes containing canonical FOXO1-, FOXO3-, or FOXO4-binding sites in their promoter regions (FOXO1: nES, 1.87; FDR, 0.01) (Fig. 4E; Supplemental Table S2). Thus, analysis of the RNA sequencing (RNA-seq) data by GSEA indicates an important role for PI3K/AKT signaling, RAS/MEK signaling, and FOXO transcription factors in the TERT ${ }^{\mathrm{High}} \mathrm{cKit}^{-}$pool of undifferentiated spermatogonia.

In TERT $^{\text {Low }}$ cKit $^{+}$differentiated spermatogonia, GSEA identified a highly significant enrichment of E2F-regulated gene sets in the data set containing up-regulated genes in this compartment. Sixteen of the top 20 gene sets in this motif analysis represented genes containing E2F family binding sites within their promoters (E2F1: nES, -2.37; FDR, 0) (Fig. 4E; Supplemental Table S2), consistent with more rapid cycling of the differentiated spermatogonia compared with the undifferentiated spermatogonia (Fig. 3D). Consistent with the more differentiated features of the $\mathrm{Tert}^{\mathrm{Low}} \mathrm{cKit}^{+}$cells, multiple gene sets pertaining to meiosis were enriched in this population, including meiotic cell cycle (nES, 2.21; FDR, 0) and meiosis I (nES, 1.99; FDR, 0.02) (Fig. 4E). Gene sets containing empirically determined cell cycle genes were also identified as being highly significant (Whitfield cell cycle literature gene set: nES, -2.72; FDR, 0). A large number of classical E2F target genes (Ren et al. 2002) were preferentially expressed in $\mathrm{Tert}^{\mathrm{Low}} \mathrm{cKit}^{+}$progenitor cells, including CCNA2 and MCM genes; E2F2, CDC25A, RRM1, TOP2A, EZH2, BRCA1, PCNA, PLK, and KIF4A; and many others (Supplemental Table S3). Surprisingly, this activation of the cell cycle program occurs in concert with marked down-regulation of the Tert promoter and telomerase, suggesting that, in the germline, telomerase expression is more closely associated with stemness than with active cell cycle.

\section{Functional GSCs are restricted to the pool of TERT $T^{\text {High }}$ undifferentiated spermatogonia}

To test the relationship between telomerase levels and stemness, we determined the potential of purified spermatogonial populations to reconstitute spermatogenesis after transplantation. FACS-purified Tert ${ }^{\mathrm{High}} \mathrm{cKit}^{-}$undifferentiated spermatogonia, Tert ${ }^{\text {High }} \mathrm{cKit}^{+}$differentiated spermatogonia, Tert ${ }^{\text {Low }} \mathrm{cKit}^{+}$differentiated spermatogonia, or unfractionated germ cells were assayed for the ability to colonize the tubules of $c K i t^{W / W_{V}}$ mice, which lack GSCs (Brinster and Zimmermann 1994). Donor cells were permanently marked by breeding Tert ${ }^{\text {Tomato/+ }}$ mice to mouse strains with ubiquitous expression of either EGFP or $\beta$-galactosidase (CAG-EGFP mice or ROSA-lacZ mice, respectively) (Fig. 5A). FACS-sorted cells from adult donors were injected separately into the seminiferous tubules of $c K i t^{W / W_{V}}$ recipients via the efferent bundle ( $n=3-4$ independent transplants per cell type) (Fig. 5A). Stringent sorting conditions led to very high purity of donor cell preparations, as confirmed by reanalysis of the sorted cells prior to transplant (Supplemental Fig. 5). Stem cell frequency in unfractionated germ cells was assessed by transplanting cells sorted only on viability. Two months after surgery, colony counts were determined by EGFP epifluorescence or lacZ staining of recipient testes (Fig. 5B). This assay is a quantitative measure of stem cell number, as each colony in the recipient mice arises from the engraftment of a single cell.
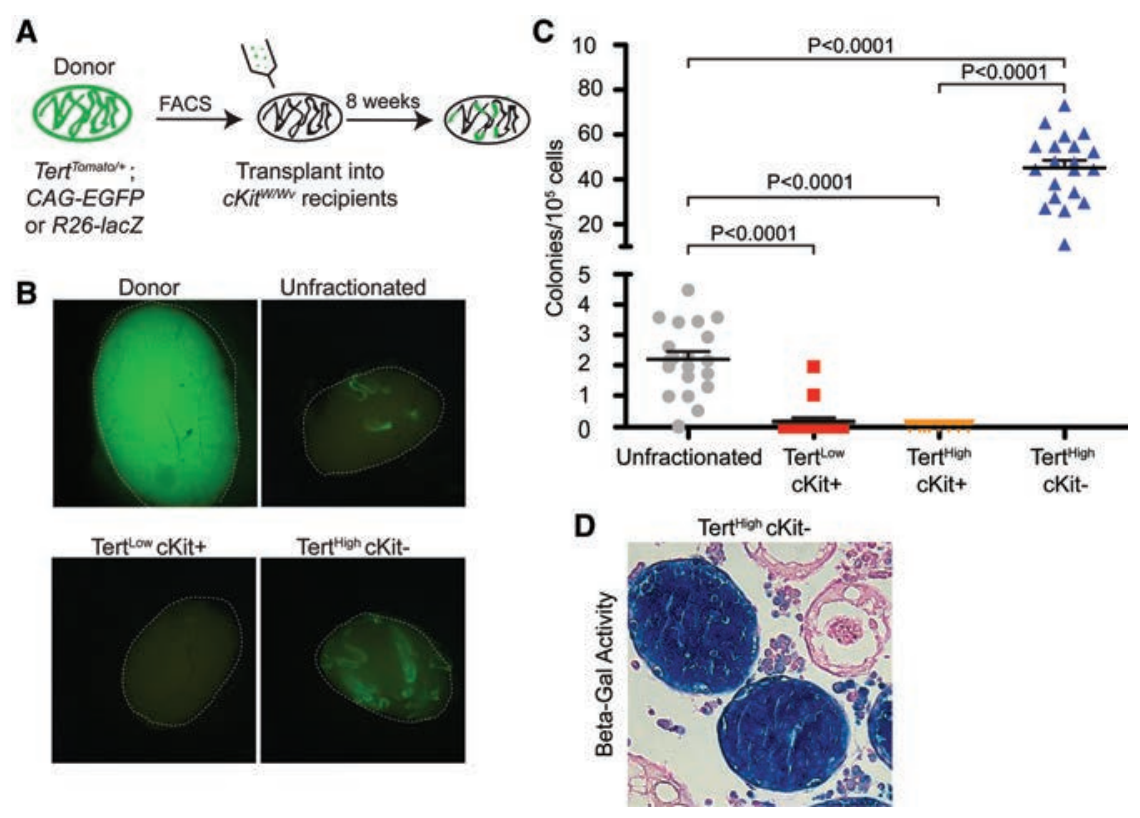

Figure 5. Tert ${ }^{\text {High }}$ undifferentiated spermatogonia comprise the functional stem cell pool. (A) Outline of transplant experiments. Tert ${ }^{\text {Tomato/+ }}$ mice were intercrossed with a strain expressing either GFP or LacZ ubiquitously. Permanently labeled Tert-Tomato cell populations were FACS-isolated and transplanted into sterile $c K i t^{W / W_{V}}$ recipients. Colonies were counted 2 mo after injection. (B) Representative EGFP epifluorescence in recipient $c \mathrm{Kit}^{\mathrm{W} / W_{V}}$ mice 2 mo after transplantation of cells shown in A. White lines represent the boundary of the testis. "Donor" shows the ubiquitous GFP fluorescence present in the donor testes. "Unfractionated" represents the transplantation of FACS-sorted DAPI ${ }^{-}$cells not fractionated by Tert-Tomato expression or immunophenotype. (C) Quantification of the transplant results shown in $B$. Colony counts were normalized to $10^{5}$ cells. Mean and SEM are shown. $P$-values are from unpaired $t$-test. $n=19-20$ recipient testes per condition, except for Tert ${ }^{\mathrm{High}} \mathrm{cKit}^{+}$transplant $(n=8)$. $(D)$ Representative histological cross-sections from transplant recipients. R26-LacZ ${ }^{+}$donor cells of the indicated immunophenotype were detected by LacZ staining. 
We found that differentiated spermatogonia were effectively incapable of reconstituting spermatogenesis. Both Tert ${ }^{\text {High }} \mathrm{cKit}^{+}$and $\mathrm{Tert}^{\mathrm{Low}} \mathrm{cKit}^{+}$cells were significantly depleted of transplant activity relative to unfractionated germ cells $(0 \pm 0$ and $0.16 \pm 0.11$ colonies per 100,000 cells, respectively; $P<0.0001$ compared with unfractionated cells). In contrast, transplant activity was restricted to the undifferentiated spermatogonial pool $\left(\mathrm{Tert}^{\mathrm{High}} \mathrm{cKit}^{-}\right)$. This population achieved 22 -fold enrichment for transplant potential compared with unfractionated germ cells $(45.1 \pm 3.4$ vs. $2.19 \pm 0.25$ colonies per 100,000 cells; $P<0.0001$ ) (Fig. 5C). We confirmed histologically that full spermatogenesis occurred after transplantation (Fig. 5D). These data indicate that undifferentiated spermatogonia, characterized by high telomerase levels, contain the pool of functional stem cells within the adult testis.

\section{Marked down-regulation of telomerase activity in somatic progenitor cells compared with germline progenitor cells}

In assessing expression of Tomato in Tert ${ }^{\text {Tomato/+ }}$ mice, we found that the reporter could not be detected in several telomerase-positive somatic tissues, including bone marrow, intestinal crypts, and liver. We wondered whether the robust expression of Tomato in spermatogonia and the absence of expression in the soma could reflect differences in telomerase expression in germline progenitor cells versus somatic progenitor cells. To address this question, we directly compared telomerase activity across multiple stem/progenitor compartments with mES cells, which express sufficient telomerase to sustain telomere length during long-term cell culture (Fig. 6A). TRAP reactions performed on equal numbers of sorted cells revealed that $\mathrm{Tert}^{\text {High }}$ ckit $^{-}$undifferentiated spermatogonia possess levels of telomerase comparable with that of mES cells (Fig. 6B). To determine relative levels of telomerase in somatic progenitor cells, we compared TRAP activity in mES cells with the stem/progenitor cells of the testis $\left(\mathrm{ITGa} 6^{\text {High }} \mathrm{cKit}^{-}\right)$, intestine $\left(\mathrm{CD} 45^{-} \mathrm{EPCAM}^{+} \mathrm{CD} 44^{\text {High }}\right.$ cells isolated from crypts of the small intestine), and bone marrow (Lineage ${ }^{-} \mathrm{Scal}^{+} \mathrm{cKit}^{+}$cells) from wild-type mice. Compared with germline stem/progenitor cells, telomerase activity was more than fourfold lower in intestinal progenitors and $>10$-fold lower in bone marrow stem/ progenitors (Fig. 6C). These data establish testis stem/progenitor cells as a cell population uniquely expressing telomerase at levels comparable with mES cells. Additionally,
A

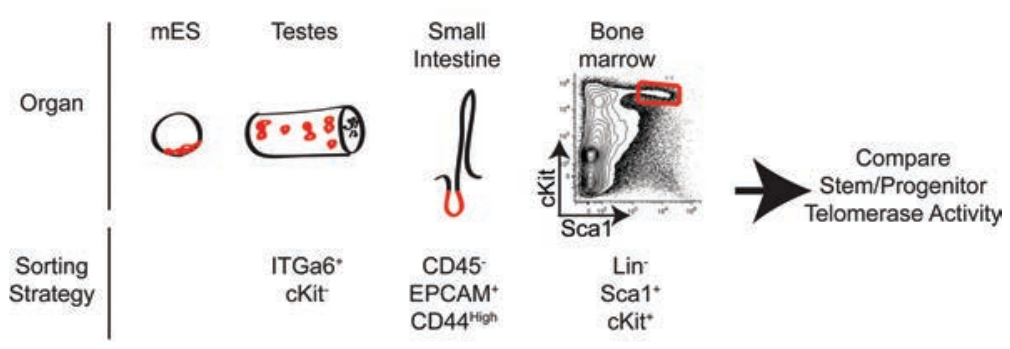

B

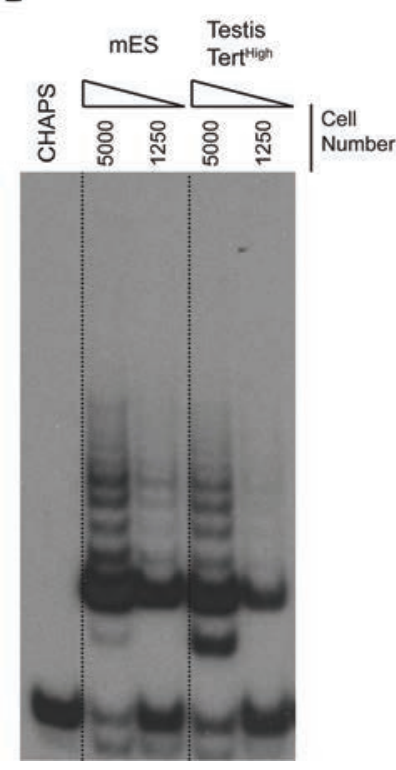

C

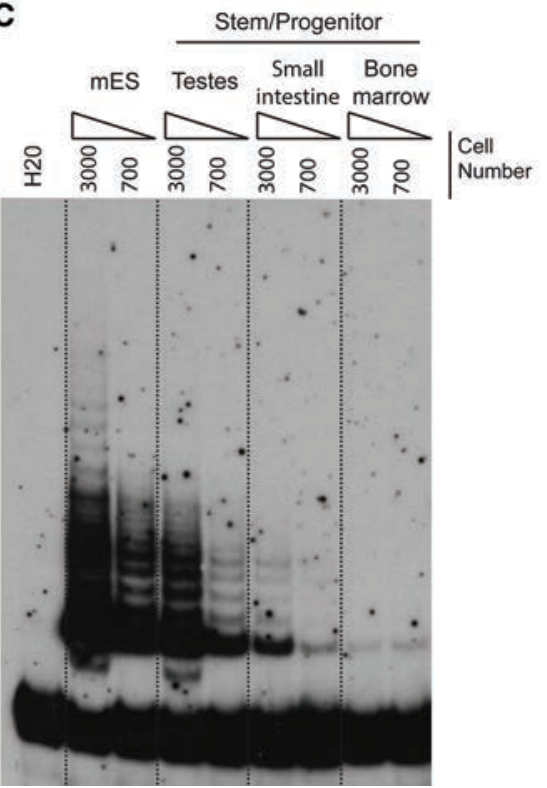

Figure 6. Marked down-regulation of telomerase activity in somatic progenitor cells compared with germline progenitor cells. (A) Experimental overview. Telomerase activity was compared between identical numbers of progenitor cells of the indicated immunophenotypes isolated from different tissues. $(B)$ Telomerase assays by TRAP using identical numbers of Tert ${ }^{\text {Tomato/+ }}$ mES cells and Tert ${ }^{\text {High }}$ testis cells from Tert ${ }^{\text {Tomato/+ }}$ mice. Dilutions represent 5000 and 1250 cell equivalents. Results representative of four independent experiments are shown. $(C)$ Telomerase assays by TRAP using FACS-purified cells of the indicated immunophenotypes from wild-type mice compared with wild-type ES cells. Dilutions represent 3000 and 700 cell equivalents, respectively. Representative results of three biological replicates are shown. 
we found that somatic organs with high replicative demands similar to those of the testis nevertheless possess much lower telomerase activity, providing a molecular explanation for the difference in telomere maintenance between the germline and the soma.

\section{Telomere dysfunction causes depletion of TERT $T^{\text {High }}$ undifferentiated spermatogonia and a loss of GSCs}

Having determined that undifferentiated spermatogonia express a uniquely high level of telomerase, we wondered whether loss of these cells could underlie the conserved dependence on telomerase for germline maintenance in metazoans. We intercrossed Tert ${ }^{\text {Tomato/+ }}$ mice to generate homozygous Tert ${ }^{\text {Tomato/Tomato }}$ mice and confirmed that telomerase was undetectable in these mice, indicating that Tert-Tomato is a null allele (Supplemental Fig. 6A). As a consequence of the long telomere reserves in laboratory mice, telomerase knockout mice are studied using a generational mating scheme. Tert ${ }^{\text {Tomato/+ }}$ heterozygotes retain telomerase activity and are termed G0. First-generation (G1) Tert ${ }^{\text {Tomato/Tomato }}$ mice lack telomerase activity but retain long functional telomeres. We intercrossed G1 Tert ${ }^{\text {Tomato/Tomato }}$ mice to yield G2 mice and subsequently mated G2 mice to create G3 mice and so on (Fig. 7A). Consistent with previous studies, we could generate no additional mice beyond G6 (Lee et al. 1998). G5 males showed diminished fertility based on reduced litter size, and G6 males were incapable of siring progeny $(P<$ 0.0001 relative to $\mathrm{G} 1$ mice) (Supplemental Fig. 6B). As previously observed, late-generation testes exhibited atrophy and loss of germ cell cellularity in a variable and stochastic fashion (Supplemental Fig. 6B,C; Chin et al. 1999).

To quantify the changes within the germline cell populations, single-cell suspensions from entire G1 Tert ${ }^{\text {Tomato/Tomato }}$ testes and G6 Tert ${ }^{\text {Tomato/Tomato }}$ testes were analyzed by flow cytometry for expression of Tert-Tomato and cKit (Fig. 7B). For this method, a G1 Tert ${ }^{\text {Tomato/Tomato }}$ age-matched control mouse was analyzed in parallel with each G6 Tert ${ }^{\text {Tomato/Tomato }}$ mouse. This method controls for variability in sample preparation and measures the relative depletion of viable cells within each spermatogonial subpopulation. Five of the six lategeneration mice had reduced overall testis size and macroscopic evidence of germ cell depletion. In those mice, the number of live germ cells was reduced, on average, 28 -fold compared with G1 controls. Importantly, these mice showed substantial depletion (average sixfold) of the undifferentiated spermatogonial pool (Tert $\left.{ }^{\mathrm{High}} \mathrm{cKit}^{-}\right)$. There was no evidence of a discrete differentiation blockade; rather, the level of reduction in Tert ${ }^{\mathrm{High}} \mathrm{cKit}^{-}$cells within a mouse dictated the depletion level of differentiated spermatogonia and meiotic cells.

We examined PLZF expression in large numbers of histological sections from late-generation (G4-G6) Tert-null mice to understand the relationship between stem cell depletion and tubular degeneration (defined as $<10$ differentiating germ cells per cross-section) (Fig. 7C). Dysfunctional telomere mice (G4-G6) exhibited a bimodal distribution of degeneration, with roughly half of the mice showing $>90 \%$ degeneration, and the other half showing moderate $(<10 \%)$ degeneration (Fig. 7D). Lategeneration mice exhibited a significant loss of $\mathrm{PLZF}^{+}$ cell density $\left(0.94 \pm 0.24\right.$ vs. $2.4 \pm 0.07 \mathrm{PLZF}^{+}$cells per tubular cross-section in G4-G6 vs. G0-G2 mice; $P<0.0001$ ) (Fig. 7E). The depletion of adult spermatogonia did not simply reflect insufficient seeding of the seminiferous tubules by neonatal GSCs. Postnatal day 6 testes from G6 mice did not show evidence of either tubular atrophy or a reduction in the number of $\mathrm{PLZF}^{+}$cells (Supplemental Fig. 6D,E).

The depletion in $\mathrm{PLZF}^{+}$cells was most dramatic in atrophic tubules; however, even nonatrophic tubules from late-generation mice had significantly fewer $\mathrm{PLZF}^{+}$cells than normal tubules from early-generation mice (average of $1.58 \mathrm{PLZF}^{+}$cells per tubule [95\% CI: 1.43-1.73] vs. 2.04 PLZF $^{+}$cells per tubule [95\% CI: 1.9-2.17; $\left.P<0.0001\right]$ ) (Fig. $7 \mathrm{~F})$. Outright tubular atrophy was preceded by a period of reduced numbers of undifferentiated spermatogonia, suggesting that spermatogenesis requires a minimum threshold number of stem cells. Consistent with this notion, the relationship between the total level of tubular degeneration within a mouse and the average number of PLZF ${ }^{+}$ cells per degenerated tubule was sigmoidal (Fig. 7G), with the dramatic rise in overall degeneration levels occurring once the average number of $\mathrm{PLZF}^{+}$cells per tubule fell below one. Interestingly, telomere dysfunction sometimes led to the presence of atrophic tubules in which meiotic germ cells were depleted but $\mathrm{PLZF}^{+}$cells remained. These residual $\mathrm{PLZF}^{+}$cells showed a significantly increased proliferative index, as measured by phosphohistone 3 staining (Fig. 7H,I). While clearly depleted, spermatogonial subtypes were relatively preserved in comparison with the more mature meiotic cell types (Fig. 7B). In atrophic tubules with residual $\mathrm{PLZF}^{+}$cells, the fraction of cells expressing GFRal was markedly increased to $70 \%$ of all $\mathrm{PLZF}^{+}$cells $(P<0.002)$ (Fig. $\left.7 \mathrm{~J}\right)$. In these depleted tubules with remaining spermatogonia, the increase in active cycling together with the elevated frequency of GFRa $1^{+}$cells suggests an attempt to restore the stem cell pool by increasing self-renewing divisions. However, this loss of quiescence likely accelerates stem cell depletion and complete tubular atrophy.

\section{Discussion}

Very high telomerase, germline immortality, and the disposable soma theory

The germline lineage prepares its genome for totipotency through a series of genetic and epigenetic modifications that occur during defined developmental time points (Saitou and Yamaji 2012). One aspect of this preparation is a uniquely effective method for maintenance of telomere lengths, the underlying mechanism for which appears to be lacking in proliferating somatic tissue compartments. By using a Tert reporter strain to identify telomerasepositive cells in vivo, we found that germline progenitor cells in adult testis express unusually elevated levels of telomerase enzyme. Telomerase levels in undifferentiated 
Pech et al.
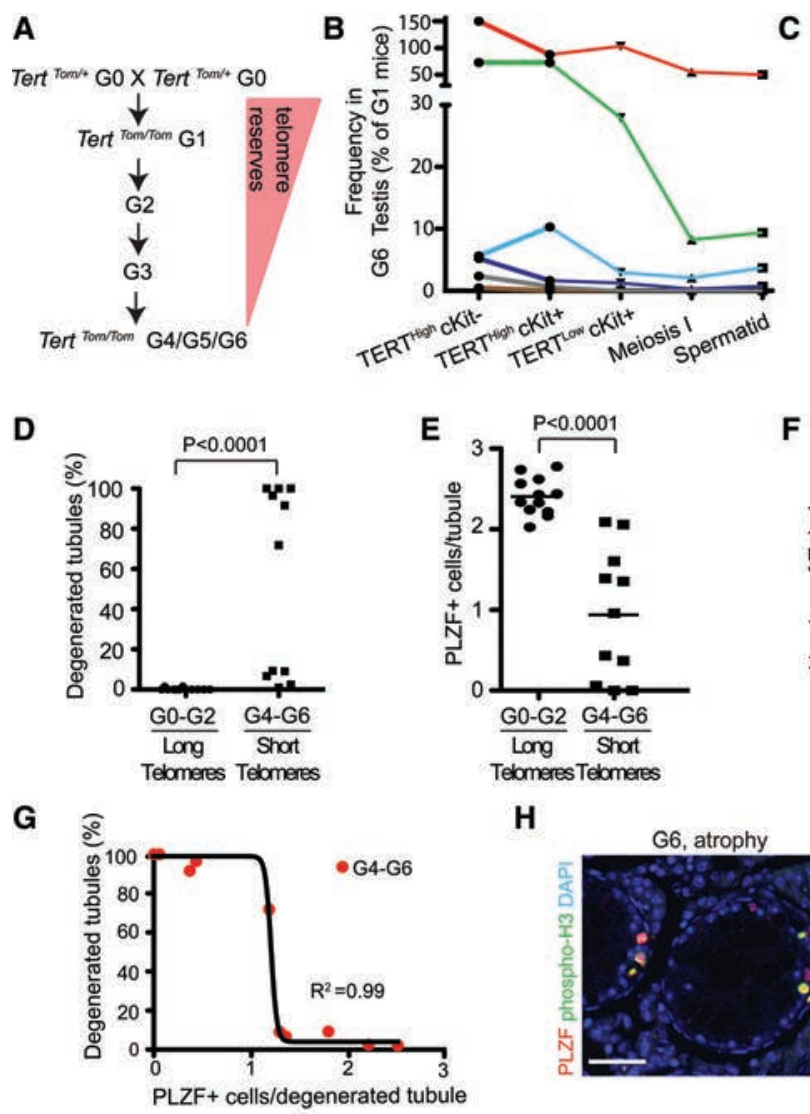

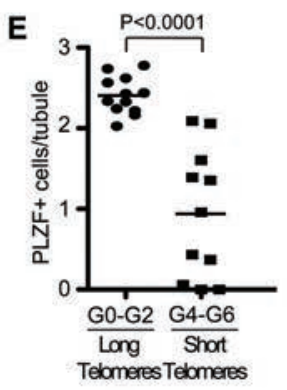

H

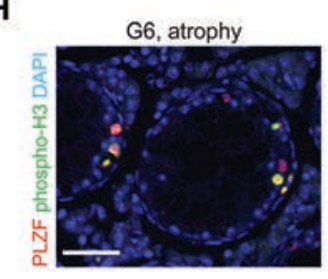

F

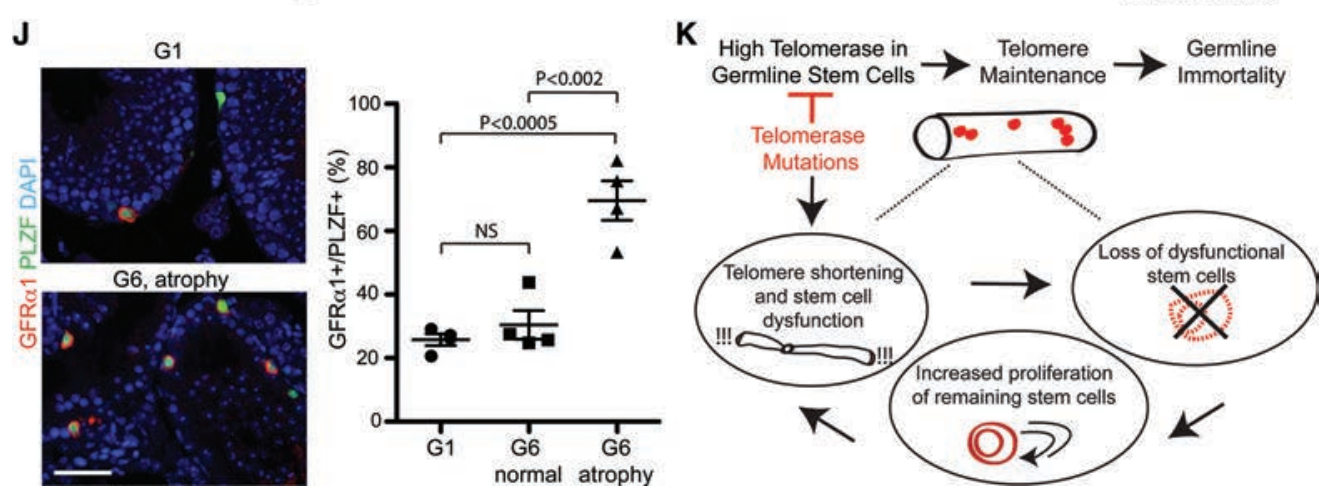

Figure 7. Telomere dysfunction depletes undifferentiated spermatogonia and induces tubular degeneration. $(A)$ Overview of generational mating strategy used to generate Tert-Tomato reporter mice with telomere dysfunction. $(B)$ Flow cytometry-based quantification of the indicated germ cell populations within the G1 and G6 testes. The total number of events for each G6 mouse was normalized to a G1 control mouse. Data points arising from the same mice are graphed in the same color. (C) PLZF staining on testes cross-sections from Tert knockout mice of the indicated generation. Bar, $50 \mu \mathrm{m} .(D, E)$ Quantification of the extent of tubular degeneration $(D)$ and the average number of PLZF $\mathrm{F}^{+}$ cells per tubule $(E)$ in generation 0-2 and generation 4-6 Tert knockout mice. The $P$-value is from the Mann-Whitney test. $n=11-12$ mice per condition. $(F)$ Histogram of $\mathrm{PLZF}^{+}$cells per normal tubule and per dysfunctional tubule in generation 0-2 and generation 4-6 Tert knockout mice. The line shows the nonlinear regression curve fitting the data. Mean is indicated with a dashed line. The $P$-value is from the MannWhitney test. $(G)$ Relationship between PLZF $^{+}$cell number per tubule cross-section and the percent of tubules showing degeneration in each G4-G6 Tert knockout mouse. The line indicates a sigmoidal curve with a variable slope fitting the data. $n=11$ mice. $(H)$ Phosphorylated histone 3 (pH3) expression in G6 atrophic tubules. Bar, $50 \mu \mathrm{m}$. (I) Quantification of proliferative status from $H$. $n=4$ mice per condition. The $P$-value is from the unpaired two-tailed $t$-test. $n=4$ mice per condition. $(J)$ GFR 1 staining in early-generation and late-generation mice. Quantification of GFR $\alpha 1^{+}$cells per PLZF ${ }^{+}$cell. $n=4$ mice per condition. The $P$-value is from the unpaired two-tailed $t$-test. $(K)$ Model for how telomerase expression in GSCs promotes germline immortality and how telomerase mutations interrupt GSC maintenance.

spermatogonia and mES cells were comparable and much greater than in intestinal or bone marrow progenitor cells. Because mES cells are able to maintain their telomeres indefinitely, we infer that very high telomerase in undifferentiated spermatogonia constitutes the principal mechanism to explain how telomere attrition is avoided 
with advancing age during human spermatogenesis. Based on our analysis of telomerase-deficient mice, we propose that maintaining telomere function specifically through very high telomerase levels in undifferentiated spermatogonia is critical for germline immortality (Fig. 7J).

The disposable soma theory, proposed by Kirkwood and Holliday (1979), hypothesizes that aging is a compromise in which limited resources are allocated to maintain the immortal germline lineage at the expense of somatic cell maintenance. Consistent with this, germ cells have lower rates of spontaneous mutation and higher DNA repair activities than somatic cells. Our data provide molecular evidence for differential genome maintenance in stem/progenitor cells from the germline compared with the soma. We cannot say whether this distinct regulation of telomerase relates to a proposed compromise in terms of limited resources. Instead, this differential regulation more likely reflects strong evolutionary pressure to maintain telomeres throughout the germline cycle. Similar evolutionary pressure to maintain telomeres in the soma may not exist; alternatively, there may be evolutionary pressure for less efficient telomere maintenance in the soma as either a cancer suppression mechanism or part of a prosomatic aging program. In either case, there clearly exists differential control of telomerase levels between the germline and the soma.

\section{Quantitative regulation of telomerase: an emerging paradigm in tissue progenitor cells and disease}

The Tert Tomato/+ knock-in reporter approach allows for TERT promoter activity to be measured at the singlecell level and enables the isolation of telomerase-positive progenitor cells by FACS. Using this approach, we discovered that undifferentiated spermatogonia express uniformly high telomerase and uncovered a gradient of telomerase activity in more differentiated germ cells. Previous studies attempting to localize telomerase expression within the germ cell lineage showed widely divergent results. A subset of the studies did find elevated expression in partially purified spermatogonia, which is consistent with our data (Ravindranath et al. 1997; Kanatsu-Shinohara et al. 2003; Riou et al. 2005).

We found that Tert promoter activity and telomerase levels are controlled in a highly stereotyped manner during the maturation of the germ cell lineage. While highest in undifferentiated spermatogonia, telomerase diminishes in a stepwise fashion in differentiated spermatogonia and meiotic cells before being shut off in haploid spermatids and mature sperm. The very high levels in the stem cell compartment ensure that telomeres are maintained at a germline set point during germline maturation. Expression of high telomerase in the stem cell population is sufficient for this purpose because long telomeres are inherited in progeny. The lower levels of telomerase in differentiated spermatogonia and meiotic cells may serve an important role in rescuing telomeres on occasion, such as from stalled replication forks. Our data indicate that germline control of Tert expression is not simply regulated by the cell cycle. Compared with Tert ${ }^{\text {High }}$ undifferentiated spermatogonia, Tert ${ }^{\text {Low }}$ differentiated spermatogonia showed a sixfold increase in S-phase fraction, concomitant with a fourfold decrease in telomerase activity. These observations indicate that telomerase levels are more closely related to proliferative potential rather than proliferative state.

Are the very high levels of telomerase in GSCs required for maintaining telomeres? Data from humans and mice with heterozygous mutations in telomerase components provide strong support for this hypothesis. Mice heterozygous for Tert show gradual telomere shortening with successive generations (Erdmann et al. 2004; Chiang et al. 2010). Similarly, families with dyskeratosis congenita caused by heterozygous mutations in TERT or TERC exhibit genetic anticipation, with progressive telomere shortening and worsening clinical phenotypes in subsequent generations (Vulliamy et al. 2001; Armanios et al. 2005). This pattern of intergenerational telomere shortening in mice and humans heterozygous for telomerase indicates that very high levels of telomerase in GSCs are, in fact, necessary for maintaining telomeres in offspring.

Our data indicate that telomerase expression is quantitatively regulated in normal tissues: differentially regulated between the germline and the soma but also differentially regulated during germ lineage maturation. The mechanisms that enable such exquisite control of levels remain to be identified. These findings in normal progenitor cells are reminiscent of findings in human disease susceptibility and cancer. Reductions in telomerase activity of $\leq 50 \%$ can result in a spectrum of diseases characterized by tissue failure, including dyskeratosis congenita, aplastic anemia, pulmonary fibrosis, and liver cirrhosis (Vulliamy et al. 2001; Yamaguchi et al. 2005; Batista et al. 2011). Conversely, somatic mutations in the Tert promoter are highly prevalent in many human cancers and increase telomerase levels (Horn et al. 2013; Huang et al. 2013; Borah et al. 2015; Chiba et al. 2015). Even more modest changes in TERT levels are anticipated in settings of germline polymorphisms predisposing to cancer or pulmonary fibrosis (Baird 2010). Thus, disruption of the fine-tuning of telomerase levels in normal progenitor cells predisposes to degenerative disease and cancer.

Our findings of highly quantitative regulation of telomerase within germline lineage and comparisons of germline and somatic progenitor cells indicate the existence of signaling pathways capable of specifying telomerase levels over a broad range. We speculate that an understanding of the signaling pathways driving these gradients in telomerase levels may lead to pharmacological interventions to treat degenerative conditions caused by telomere shortening.

\section{Molecularly defining spermatogonia and how telomere dysfunction compromises tissue homeostasis}

Our data provide a roadmap for how a tissue can be dissected based on Tert promoter activity. In the germline, this approach enabled the robust isolation of defined 
spermatogonial subtypes, including undifferentiated spermatogonia. This approach overcomes a significant technical barrier in isolating these cells from adult mice, which has limited their molecular and functional characterization. With the capability to isolate undifferentiated spermatogonia, we rigorously show that transplantable stem cells are specifically found within this fraction. Recent research has uncovered substantial heterogeneity of undifferentiated spermatogonia. Most notably, the subset of GFRa1-expressing cells has been proposed to represent the GSC pool, with the remainder of mostly NGN3-expressing cells heavily biased toward differentiation (Nakagawa et al. 2010; Hara et al. 2014). Our approach of isolating purified populations of cells for molecular and functional analyses has potential for revealing new insights into subpopulations of undifferentiated spermatogonia.

Studies on the consequences of critically short telomeres in somatic stem/progenitor cells from other mouse tissues have typically found these populations to be marginally affected homeostatically but functionally compromised when forced to mobilize, such as upon transplant or in vitro proliferation (Allsopp et al. 2003; Rossi et al. 2007). In contrast, we found that telomere dysfunction dramatically depleted the Tert ${ }^{\text {High }}$ undifferentiated spermatogonia stem cell pool, disrupting the male germline cycle at the top of the lineage hierarchy. We detected abnormally proliferative $\mathrm{PLZF}^{+}$cells in otherwise atrophic zones. This increase in proliferation likely reflects an attempt among the residual (telomere-functional) stem cells to restore organ homeostasis, with niche signaling biasing the cells toward self-renewing divisions. However, this loss of quiescence may only accelerate telomere shortening and the onset of complete germ cell loss (Fig. 7K). Previous studies found that telomere dysfunction was specifically recognized and induced cell death at the onset of meiosis I (Hemann et al. 2001). Our analysis does not rule out the existence of a meiotic telomere checkpoint but suggests that GSC depletion is ultimately responsible for disrupting spermatogenesis. The progressive loss of GSCs in late-generation Tert knockout mice provides a framework for interpreting how tissues such as bone marrow, lung epithelium, and the liver fail in patients with telomerase deficiency.

\section{Materials and methods}

A TdTomato-pA cassette was introduced into the initiating methionine of mTert using standard mES targeting methods. Directed differentiation toward the adipocyte lineage was performed as described (Dani et al. 1997). Telomerase enzymatic assays were performed on identical numbers of FACS-sorted cells, following the manufacturer's protocol (Chemicon/Millipore). Late- generation telomerase knockout mice were generated using standard cousin mating schemes. Mice were kept on a C57BL/6 or B6/ 129 background. All mice were treated in accordance with Association for Assessment and Accreditation of Laboratory Animal Care-approved guidelines at Stanford University.

Testes were dissociated for FACS based on standard two-step protocols (Brinster and Zimmermann 1994). All FACS experiments were performed on a BD Aria II machine equipped with a 561-nm laser. Germ cell transplantations were performed as pre- viously described (Ogawa et al. 1997). Microscopy of testicular tubules and transplant experiments were performed based on published protocols (Nakagawa et al. 2010). RNA-seq of FACSpurified cells was performed using Nugen Ovation-based cDNA amplification and Illumina TruSeq library preparation. Sequencing data were deposited at the NCBI Sequence Read Archive (PRJNA300448).

\section{Acknowledgments}

We thank M. Fuller, R. Nusse, J. Sage, A. Oro, J. Lipsick, D. Knowles, and F. Zhong for their comments and suggestions. We thank D. Gilison and P. Rajaraman for contributing certain telomerase knockout samples. We acknowledge the Stanford Neuroscience Microscopy Service (supported by National Institutes of Health NS069375), and the Stanford Shared FACS Facility. This work was supported by grants from the National Institutes of Health (CA111691, CA125453, AG033747, and AG036695) and support from the Glenn Foundation for Medical Research. M.P. was supported by a National Science Foundation National Research Service Award fellowship and a T32 training grant (CA09302). A.G. was funded by a National Science Foundation National Research Service Award fellowship.

\section{References}

Allsopp RC, Vaziri H, Patterson C, Goldstein S, Younglai EV, Futcher AB, Greider CW, Harley CB. 1992. Telomere length predicts replicative capacity of human fibroblasts. Proc Natl Acad Sci 89: 10114-10118.

Allsopp RC, Morin GB, DePinho R, Harley CB, Weissman IL. 2003. Telomerase is required to slow telomere shortening and extend replicative lifespan of HSCs during serial transplantation. Blood 102: 517-520.

Aloisio GM, Nakada Y, Saatcioglu HD, Pena CG, Baker MD, Tarnawa ED, Mukherjee J, Manjunath $\mathrm{H}$, Bugde A, Sengupta AL, et al. 2014. PAX7 expression defines germline stem cells in the adult testis. J Clin Invest 124: 3929-3944.

Armanios M, Blackburn EH. 2012. The telomere syndromes. Nat Rev Genet 13: 693-704.

Armanios M, Chen JL, Chang YP, Brodsky RA, Hawkins A, Griffin CA, Eshleman JR, Cohen AR, Chakravarti A, Hamosh A, et al. 2005. Haploinsufficiency of telomerase reverse transcriptase leads to anticipation in autosomal dominant dyskeratosis congenita. Proc Natl Acad Sci 102: 15960-15964.

Artandi SE, DePinho RA. 2010. Telomeres and telomerase in cancer. Carcinogenesis 31: 9-18.

Baird DM. 2010. Variation at the TERT locus and predisposition for cancer. Expert Rev Mol Med 12: el6.

Baird DM, Rowson J, Wynford-Thomas D, Kipling D. 2003. Extensive allelic variation and ultrashort telomeres in senescent human cells. Nat Genet 33: 203-207.

Batista LF, Pech MF, Zhong FL, Nguyen HN, Xie KT, Zaug AJ, Crary SM, Choi J, Sebastiano V, Cherry A, et al. 2011. Telomere shortening and loss of self-renewal in dyskeratosis congenita induced pluripotent stem cells. Nature 474: 399-402.

Borah S, Xi L, Zaug AJ, Powell NM, Dancik GM, Cohen SB, Costello JC, Theodorescu D, Cech TR. 2015. Cancer. TERT promoter mutations and telomerase reactivation in urothelial cancer. Science 347: 1006-1010.

Brinster RL, Zimmermann JW. 1994. Spermatogenesis following male germ-cell transplantation. Proc Natl Acad Sci 91: 11298-11302. 
Buaas FW, Kirsh AL, Sharma M, McLean DJ, Morris JL, Griswold MD, de Rooij DG, Braun RE. 2004. Plzf is required in adult male germ cells for stem cell self-renewal. Nat Genet 36: 647-652.

Chan F, Oatley MJ, Kaucher AV, Yang QE, Bieberich CJ, Shashikant CS, Oatley JM. 2014. Functional and molecular features of the $\mathrm{Id} 4^{+}$germline stem cell population in mouse testes. Genes Dev 28: 1351-1362.

Chiang YJ, Calado RT, Hathcock KS, Lansdorp PM, Young NS, Hodes RJ. 2010. Telomere length is inherited with resetting of the telomere set-point. Proc Natl Acad Sci 107: 10148-10153.

Chiba K, Johnson JZ, Vogan JM, Wagner T, Boyle JM, Hockemeyer D. 2015. Cancer-associated TERT promoter mutations abrogate telomerase silencing. Elife 4. doi: 10.7554/ eLife.07918.

Chin L, Artandi SE, Shen Q, Tam A, Lee SL, Gottlieb GJ, Greider CW, DePinho RA. 1999. p53 deficiency rescues the adverse effects of telomere loss and cooperates with telomere dysfunction to accelerate carcinogenesis. Cell 97: 527-538.

Cinalli RM, Rangan P, Lehmann R. 2008. Germ cells are forever. Cell 132: 559-562.

Costoya JA, Hobbs RM, Barna M, Cattoretti G, Manova K, Sukhwani M, Orwig KE, Wolgemuth DJ, Pandolfi PP. 2004. Essential role of Plzf in maintenance of spermatogonial stem cells. Nat Genet 36: 653-659.

d'Adda di Fagagna F, Reaper PM, Clay-Farrace L, Fiegler H, Carr P, Von Zglinicki T, Saretzki G, Carter NP, Jackson SP. 2003. A DNA damage checkpoint response in telomere-initiated senescence. Nature 426: 194-198.

Dani C, Smith AG, Dessolin S, Leroy P, Staccini L, Villageois P, Darimont C, Ailhaud G. 1997. Differentiation of embryonic stem cells into adipocytes in vitro. I Cell Sci 110(Pt 11): 1279-1285.

de Lange T, Shiue L, Myers RM, Cox DR, Naylor SL, Killery AM, Varmus HE. 1990. Structure and variability of human chromosome ends. Mol Cell Biol 10: 518-527.

de Rooij DG. 1973. Spermatogonial stem cell renewal in the mouse. I. Normal situation. Cell Tissue Kinet 6: 281-287.

de Rooij DG, Russell LD. 2000. All you wanted to know about spermatogonia but were afraid to ask. J Androl 21: 776-798.

Erdmann N, Liu Y, Harrington L. 2004. Distinct dosage requirements for the maintenance of long and short telomeres in mTert heterozygous mice. Proc Natl Acad Sci 101: 6080-6085.

Goertz MJ, Wu Z, Gallardo TD, Hamra FK, Castrillon DH. 2011. Foxol is required in mouse spermatogonial stem cells for their maintenance and the initiation of spermatogenesis. J Clin Invest 121: 3456-3466.

Hara K, Nakagawa T, Enomoto H, Suzuki M, Yamamoto M, Simons BD, Yoshida S. 2014. Mouse spermatogenic stem cells continually interconvert between equipotent singly isolated and syncytial states. Cell Stem Cell 14: 658-672.

Harel I, Benayoun BA, Machado B, Singh PP, Hu CK, Pech MF, Valenzano DR, Zhang E, Sharp SC, Artandi SE, et al. 2015. A platform for rapid exploration of aging and diseases in a naturally short-lived vertebrate. Cell 160: 1013-1026.

Hemann MT, Rudolph KL, Strong MA, DePinho RA, Chin L, Greider CW. 2001. Telomere dysfunction triggers developmentally regulated germ cell apoptosis. Mol Biol Cell 12: 2023-2030.

Henriques CM, Carneiro MC, Tenente IM, Jacinto A, Ferreira MG. 2013. Telomerase is required for zebrafish lifespan. PLoS Genet 9: e1003214.
Horn S, Figl A, Rachakonda PS, Fischer C, Sucker A, Gast A, Kadel S, Moll I, Nagore E, Hemminki K, et al. 2013. TERT promoter mutations in familial and sporadic melanoma. Science 339: 959-961.

Huang FW, Hodis E, Xu MJ, Kryukov GV, Chin L, Garraway LA. 2013. Highly recurrent TERT promoter mutations in human melanoma. Science 339: 957-959.

Huckins C. 1971. The spermatogonial stem cell population in adult rats. I. Their morphology, proliferation and maturation. Anat Rec 169: 533-557.

Kanatsu-Shinohara M, Ogonuki N, Inoue K, Miki H, Ogura A, Toyokuni S, Shinohara T. 2003. Long-term proliferation in culture and germline transmission of mouse male germline stem cells. Biol Reprod 69: 612-616.

Kirkwood TB, Holliday R. 1979. The evolution of ageing and longevity. Proc R Soc Lond B Biol Sci 205: 531-546.

Lee HW, Blasco MA, Gottlieb GJ, Horner JW II, Greider CW, DePinho RA. 1998. Essential role of mouse telomerase in highly proliferative organs. Nature 392: 569-574.

Lee J, Kanatsu-Shinohara M, Inoue K, Ogonuki N, Miki H, Toyokuni S, Kimura T, Nakano T, Ogura A, Shinohara T. 2007. Akt mediates self-renewal division of mouse spermatogonial stem cells. Development 134: 1853-1859.

Lee J, Kanatsu-Shinohara M, Morimoto H, Kazuki Y, Takashima S, Oshimura M, Toyokuni S, Shinohara T. 2009. Genetic reconstruction of mouse spermatogonial stem cell self-renewal in vitro by Ras-cyclin D2 activation. Cell Stem Cell 5: 76-86.

Meier B, Clejan I, Liu Y, Lowden M, Gartner A, Hodgkin J, Ahmed S. 2006. trt-1 is the Caenorhabditis elegans catalytic subunit of telomerase. PLoS Genet 2: e18.

Meyerson M, Counter CM, Eaton EN, Ellisen LW, Steiner P, Caddle SD, Ziaugra L, Beijersbergen RL, Davidoff MJ, Liu Q, et al. 1997. hEST2, the putative human telomerase catalytic subunit gene, is up-regulated in tumor cells and during immortalization. Cell 90: 785-795.

Nakagawa T, Sharma M, Nabeshima Y, Braun RE, Yoshida S. 2010. Functional hierarchy and reversibility within the murine spermatogenic stem cell compartment. Science 328: 62-67.

Oakberg EF. 1971. Spermatogonial stem-cell renewal in the mouse. Anat Rec 169: 515-531.

Ogawa T, Arechaga JM, Avarbock MR, Brinster RL. 1997. Transplantation of testis germinal cells into mouse seminiferous tubules. Int J Dev Biol 41: 111-122.

Ohbo K, Yoshida S, Ohmura M, Ohneda O, Ogawa T, Tsuchiya H, Kuwana T, Kehler J, Abe K, Scholer HR, et al. 2003. Identification and characterization of stem cells in prepubertal spermatogenesis in mice. Dev Biol 258: 209-225.

Palm W, de Lange T. 2008. How shelterin protects mammalian telomeres. Annu Rev Genet 42: 301-334.

Phillips BT, Gassei K, Orwig KE. 2010. Spermatogonial stem cell regulation and spermatogenesis. Philos Trans $R$ Soc Lond $B$ Biol Sci 365: 1663-1678.

Ravindranath N, Dalal R, Solomon B, Djakiew D, Dym M. 1997. Loss of telomerase activity during male germ cell differentiation. Endocrinology 138: 4026-4029.

Ren B, Cam H, Takahashi Y, Volkert T, Terragni J, Young RA, Dynlacht BD. 2002. E2F integrates cell cycle progression with DNA repair, replication, and $\mathrm{G}_{2} / \mathrm{M}$ checkpoints. Genes Dev 16: 245-256.

Riou L, Bastos H, Lassalle B, Coureuil M, Testart J, Boussin FD, Allemand I, Fouchet P. 2005. The telomerase activity of adult mouse testis resides in the spermatogonial a6-integrin-positive side population enriched in germinal stem cells. Endocrinology 146: 3926-3932. 
Rossi DJ, Bryder D, Seita J, Nussenzweig A, Hoeijmakers J, Weissman IL. 2007. Deficiencies in DNA damage repair limit the function of haematopoietic stem cells with age. Nature 447: 725-729.

Saitou M, Yamaji M. 2012. Primordial germ cells in mice. Cold Spring Harb Perspect Biol 4: a008375.

Schrans-Stassen BH, van de Kant HJ, de Rooij DG, van Pelt AM. 1999. Differential expression of c-kit in mouse undifferentiated and differentiating type A spermatogonia. Endocrinology 140: 5894-5900.

Shinohara T, Avarbock MR, Brinster RL. 1999. $\beta 1$ - and a6-integrin are surface markers on mouse spermatogonial stem cells. Proc Nat1 Acad Sci 96: 5504-5509.

Shinohara T, Orwig KE, Avarbock MR, Brinster RL. 2000. Spermatogonial stem cell enrichment by multiparameter selection of mouse testis cells. Proc Natl Acad Sci 97: 8346-8351.

Smelick C, Ahmed S. 2005. Achieving immortality in the C. elegans germline. Ageing Res Rev 4: 67-82.

Spradling A, Fuller MT, Braun RE, Yoshida S. 2011. Germline stem cells. Cold Spring Harb Perspect Biol 3: a002642.

Subramanian A, Tamayo P, Mootha VK, Mukherjee S, Ebert BL, Gillette MA, Paulovich A, Pomeroy SL, Golub TR, Lander
ES, et al. 2005. Gene set enrichment analysis: a knowledgebased approach for interpreting genome-wide expression profiles. Proc Nat1 Acad Sci 102: 15545-15550.

Suzuki H, Ahn HW, Chu T, Bowden W, Gassei K, Orwig K, Rajkovic A. 2012. SOHLH1 and SOHLH2 coordinate spermatogonial differentiation. Dev Biol 361: 301-312.

Takai H, Smogorzewska A, de Lange T. 2003. DNA damage foci at dysfunctional telomeres. Curr Biol 13: 1549-1556.

Vulliamy T, Marrone A, Goldman F, Dearlove A, Bessler M, Mason PJ, Dokal I. 2001. The RNA component of telomerase is mutated in autosomal dominant dyskeratosis congenita. $\mathrm{Na}$ ture 413: 432-435.

Yamaguchi H, Calado RT, Ly H, Kajigaya S, Baerlocher GM, Chanock SI, Lansdorp PM, Young NS. 2005. Mutations in TERT, the gene for telomerase reverse transcriptase, in aplastic anemia. N Engl J Med 352: 1413-1424.

Yeom YI, Fuhrmann G, Ovitt CE, Brehm A, Ohbo K, Gross M, Hubner K, Scholer HR. 1996. Germline regulatory element of Oct-4 specific for the totipotent cycle of embryonal cells. Development 122: 881-894.

Zalenskaya IA, Zalensky AO. 2002. Telomeres in mammalian male germline cells. Int Rev Cytol 218: 37-67. 


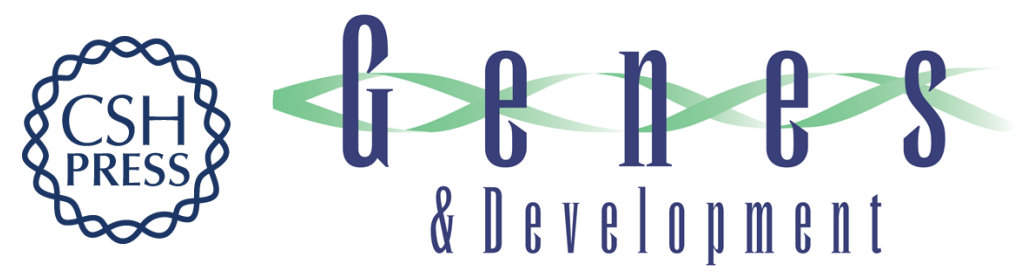

\title{
High telomerase is a hallmark of undifferentiated spermatogonia and is required for maintenance of male germline stem cells
}

\author{
Matthew F. Pech, Alina Garbuzov, Kazuteru Hasegawa, et al.
}

Genes Dev. 2015, 29: originally published online November 19, 2015

Access the most recent version at doi:10.1101/gad.271783.115

\section{Supplemental http://genesdev.cshlp.org/content/suppl/2015/11/19/gad.271783.115.DC1 Material}

References This article cites 62 articles, 22 of which can be accessed free at: http://genesdev.cshlp.org/content/29/23/2420.full.html\#ref-list-1

Creative This article is distributed exclusively by Cold Spring Harbor Laboratory Press for the first Commons six months after the full-issue publication date (see

License http://genesdev.cshlp.org/site/misc/terms.xhtml). After six months, it is available under a Creative Commons License (Attribution-NonCommercial 4.0 International), as described at http://creativecommons.org/licenses/by-nc/4.0/.

Email Alerting Receive free email alerts when new articles cite this article - sign up in the box at the top Service right corner of the article or click here.

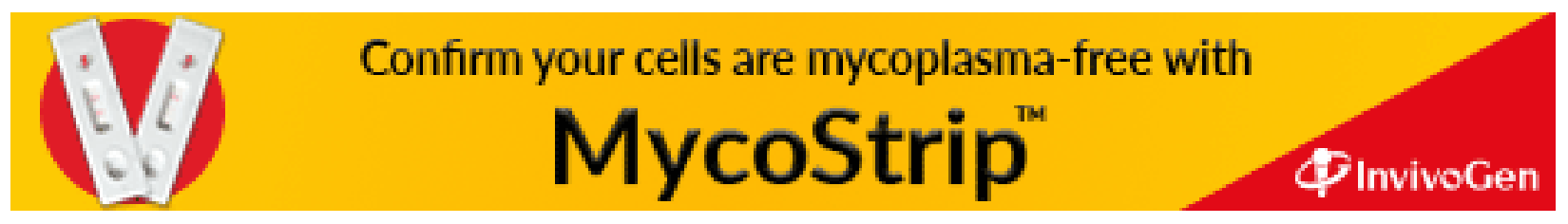

